\title{
Odun Kökenli Malzemelerin Takviyesi ile Oluşturulan Polilaktik Asit Matrisli Kompozitler
}

\author{
Hatice YAPRAK AYDIN ${ }^{1 *}$, Suat ALTUN ${ }^{1}$ \\ ${ }^{1}$ Karabük Üniversitesi, Teknoloji Fakültesi, Endüstriyel Tasarım Mühendisliği Bölümü,78050, KARABÜK
}

\section{Öz}

Bu derleme çalışmasında, son 10 yılda odun kökenli doğal liflerin polilaktik asit matrisine takviyesi ile oluşturulan kompozit malzemeler üzerine yapılan çalışmalar incelenmiştir. Odun kökenli doğal lifler, güçlü, hafif ve düşük ağırlıkta, yüksek özgül mukavemete sahip, ucuz, çevre dostu ve doğada biyolojik olarak parçalanabilir özelliklerde olduğundan polimer matrisli kompozitlerde kullanımı yaygındır. Genel olarak lifler, odun, sisal, kenevir, keten, kenaf ve bambu gibi bitki kaynaklı doğal malzemelerden elde edilmektedir. Odun unu, odun lifi, selüloz lifi, mikrokristalin selüloz ve selüloz nano parçacıklar gibi elde edilen bu malzemeler, polilaktik asit polimer matrisine takviye edilerek, mekanik özelliklerinin geliştirilmesi sağlanmaktadır. Bu çalışmada, polilaktik asit polimer matrisine odun kökenli malzemelerin takviyesi ile üretilen kompozit malzemelerin mekanik özellikleri, üretim teknikleri, takviye elamanlarının polilaktik asit matrisi üzerine etkileri, ilave edilen takviye oranları, ara yüz malzemelerin etkileri üzerine yapılmış çalışmalar incelenerek, elde edilen tüm bulgular ve sonuçlar özetlenmiştir.

Anahtar Kelimeler: PLA, odun unu, doğal lifler, odun polimer kompozitler

\section{Polylactic Acid Matrix Composites Created by the Reinforcement of Wood Original Materials}

\begin{abstract}
In this compilation study, studies on composite materials created by the reinforcement of natural fibers of wood origin into the polylactic acid matrix over the last 10 years were examined. Natural fibers of wood origin are strong, light, and low weight, have high specific strength, are cheap, environmentally friendly and biodegradable in nature, so their use in polymer matrix composites is common. In general, fibers are derived from plant-derived natural materials such as wood, sisal, hemp, flax, kenaf and bamboo. These materials, such as wood flour, wood fiber, cellulose fiber, microcrystalline cellulose, and cellulose nano particles, are reinforced into the polylactic acid polymer matrix to improve their mechanical properties. In this study, mechanical properties of composite materials produced by decoction of wood-based materials to polylactic acid polymer matrix, production techniques, effects of reinforcement elements on polylactic acid Matrix, reinforcement ratios added, effects of interface materials were examined and all findings and results were summarized.
\end{abstract}

Keywords: PLA, wood flour, natural fibers, wood polymer composites.

\footnotetext{
* Hatice YAPRAK AYDIN (Doktora Öğrencisi) Karabük Üniversitesi, Teknoloji Fakültesi, Endüstriyel Tasarım Mühendisliği Bölümü,78050, Karabük-Türkiye. 


\section{Giriş}

Kompozit malzemeler ilk olarak, 20. yüzyılın ortalarında, modern teknolojinin beklentilerini karşılayabilecek potansiyele sahip olduğu düşünülen, umut verici bir mühendislik malzemesi olarak ortaya çıkmıştır (Vasiliev ve Morozov, 2018). Kompozit malzeme, fiziksel veya kimyasal özellikleri farklı iki veya daha fazla malzemenin bir araya getirilerek, gelişmiş üstün özelliklere sahip üçüncü bir malzemeyle sonuçlanan makroskopik bir kombinasyondur (Kushwaha ve Bagha 2020). Kompozit malzemelerden ağırlıkça düşük olanı takviye elemanı, yüksek olanı ise matris fazıdır. Kompozit malzemelerin geleneksel malzemelere göre daha avantajlı olmasının nedenleri, elde edilen yeni malzemenin yapısal tasarımın çok daha yönlü olması ile ortaya çıkan yüksek özgül mukavemet, sertlik ve yorulma gibi özellikler olarak sıralanabilir. Ayrıca, kompozitler, zayıf matris malzemesine gömülü, güçlü mekanik özellikleri olan takviye yani yük taşıma malzemesi içeren malzemeler olarak da bilinir. Takviye elemanların kullanım amacı, yapısal yükün desteklenmesine yardımcı olarak daha güçlü daha sağlam yapılar oluşturmaktır (Koodalingam vd., 2020). Kompozitler sağladıkları avantajlar sayesinde otomobil, uçak ve gemi imalat sanayilerinde yaygın olarak kullanılmaktadır (Kushwaha ve Bagha, 2020).

Kompozit malzemeler organik polimer, metalik ve seramik malzemeler olarak gruplandirılabilir (İşmal ve Paul, 2017). Polimer matrisli kompozitler genellikle, matris malzemesi polimer reçinelerinden oluşan, farklı takviye malzemelerinin kullanıldığı, ticari olarak üretilen kompozitlerdir (Saxena vd., 2011). Ayrıca, polimer matrisli kompozitler, termoset veya termoplastik matris içerisine dağınık halde gömülü karbon, cam, metal, lif gibi takviye fazından oluşurlar (Haghshenas, 2016). Metal matrisli kompozitler, matris malzemesi metal olmak üzere takviye elemanları ile güçlendirilmiş en az iki bileşen parçasına sahip kompozit malzemelerdir. Takviye malzemesi, farklı bir metal, seramik veya organik yapılı bileşikler olabilir (Saxena vd., 2011). Seramik matrisli kompozitler ise, seramik bir matris malzemesine gömülü takviye fazı seramik elyaflardan oluşan güçlendirilmiş malzemelerdir (Zhang, 2014).

$\mathrm{Bu}$ derlemede, son 10 yılda odun kökenli doğal liflerin, polilaktik asit (PLA) matrisine takviyesi ile oluşturulan polimer kompozitler ile ilgili yapılan çalışmalar incelenmiştir. Odun kökenli kompozitlerin takviyesi ile oluşturulan PLA matrisli kompozitlerin, mukavemet, özgül ağırlık, süneklik, sertlik gibi mekanik özelliklerinde meydana gelen değişikler belirtilerek, uygulanabilirlikleri üzerine yapılan çalışmalar özetlenmiştir. Yapılan çalışmalarda kullanılan teknikler, takviye elemanların bileşimde kullanılan oranlar ve bu oranların PLA matrisi üzerine oluşturduğu etkiler gösterilmiştir.

\section{Polimer Matrisli Kompozitler}

Polimer matrisli kompozitler, matris bileşeni olarak organik polimer ve takviye elemanı olarak lif kullanılan malzemelerdir. Lif malzemesinin mukavemeti ve elastik modülü, normal matris malzemesinden çok daha yüksektir (Wang vd., 2011). Sağladıkları yüksek özgül mukavemet ve korozyon direnci nedeniyle, önemli bir yapısal malzeme olan polimer matrisli kompozit malzemelerin kullanımına ilgi çok fazladır. Bu yüzden, mekanik özelliklerin etkili bir şekilde geliştirilmesi, daha hafif yapısal ürünlerin tasarımı ve üretimi için uygun olması sebebiyle yaygın olarak kullanılmaktadır (Kathavate vd., 2020). Mekanik özellikleri geliştirilmiş bu kompozitlerin uçak, otomotiv, inşaat ve elektronik bileşenler gibi hafif yapılı mühendislik malzemelerinde kullanımı tercih edilmektedir (Nagaraja vd., 2020).

Polimer kompozit malzemeler, iki ana polimer grubu olan termoplastik ve termoset matris malzemelerinden oluşurlar. Termoplastik naylon, akrilik, polietilen, polistiren gibi polimer çeşitlerinden oluşan, 1Sı basınç yardımıyla yeniden şekillendirilebilen ve tekrar eritilerek kullanılabilen malzemelerdir. Diğer yandan termosetler ise, epoksiler, poliamidler, polyesterler gibi polimer türlerinden oluşan, bir defaya mahsus olmak şartıyla 1sı ve basınç yoluyla şekillendirilebilen malzemelerdir. $\mathrm{Bu}$ polimer matrislerine liflerin eklenmesi ile oluşturulan kompozit malzemeler, istenilen biçim ve boyutlarda şekillendirilebilir. Korozyona karşı sağladıkları kuvvetli dirençle birlikte yüksek mukavemet ve sertlik gibi davranışlar sergilerler. Yüksek mekanik özelliklere sahip olması, üretim maliyetinin düşük ve üretim proseslerinin kolay olması, kullanımının yaygın olmasının nedenleri arasında sıralanabilir. Polimer kompozit malzemelerin bileşenlerinin düşük yoğunluğa sahip olmaları, üstün spesifik özellikler sergilemelerine neden olur. Bu malzemelerde genellikle takviye malzemesi, doğal ve sentetik elyaf parçacıklarıdır (Sabari Narayanan ve Senthil Kumar, 2020) (Koodalingam vd., 2020). Şekil 1'de polimer matrisi olarak kullanılan biyobozunur polimer malzemeleri sınıflandırılmıştır. 


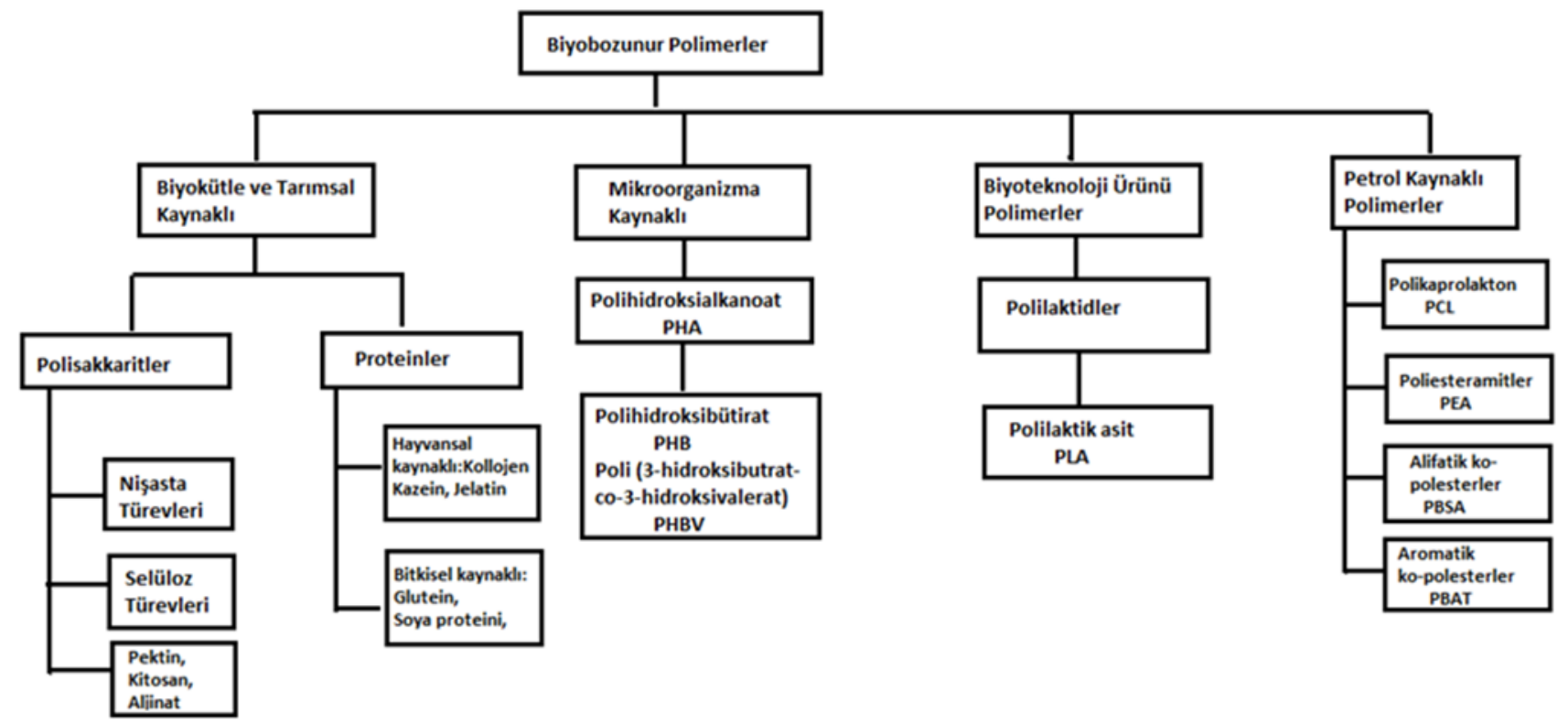

Şekil 1. Biyobozunur polimerlerin sınıflandırılması (Averous ve Boquillon, 2004)

\section{Odun Kökenli Dolgu Malzemeleri}

Son y1llarda, çevre dostu ve biyolojik olarak parçalanabilir kompozit malzemelerin üretimde doğal lif malzemelerin kullanımı çok yaygınlaşmıştır. Bunlar, keten, pamuk, kenevir, sisal, kenaf (Hint bitkisi), pirinç kabuğu, muz, bambu gibi doğal bitkilerden elde edilen kompozit malzemelerdir (Ramesh, 2016). Elyaf takviyesi, kırılgan polimer matrislere tokluk ve süneklik sağlamak için yaygın olarak kullanılan ve elde edilen kompozit malzemenin istenen özelliklerinin geliştirilebilmesi için ilave edilen dolgu malzemeleridir (Sarangi ve Sinha, 2016). Lifler, düşük yoğunluk ve maliyetin yanı sıra yüksek özgül mukavemet, sertlik ve nispeten iyi enerji emici özellikler gibi tatmin edici mekanik özelliklere sahiptir. Bu hammaddelerin, kolay bulunabilirliği ve yenilenebilirliği nedeniyle kullanımı çok caziptir (Ramu vd., 2019).

Lifler doğal ve sentetik lifler olmak üzere iki sınıfa ayrılır. Doğal lifler; hayvansal, bitki ve mineral lifleri olarak sınıflandırılır. Sentetik lifler ise organik ve inorganik liflerden oluşur (Balla vd., 2019). Şekil 2'de doğal ve sentetik liflerin sınıflandırılma şeması verilmiştir. 


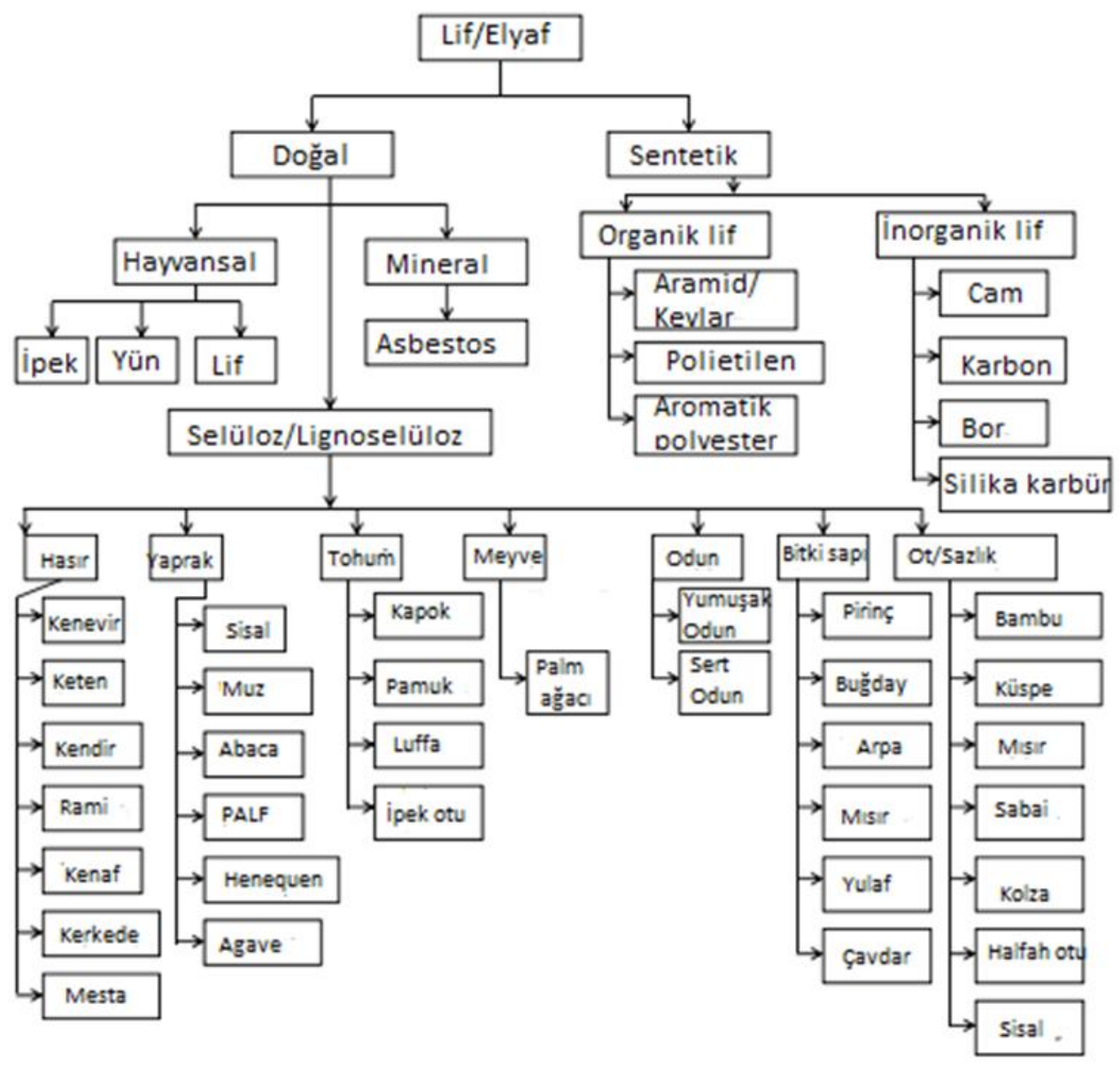

Şekil 2. Liflerin sınıflandırılması (Ramu vd., 2019).

\section{Odun Kökenli Malzemelerin Özellikleri}

Odun diğer doğal malzemelerden farklı olarak karmaşık bir anatomiye sahiptir. Odun yapısal olarak, gözenekli, lifli ve anizotropiktir. Ağaçlar geniş yapraklı ve iğne yapraklı ağaç türleri olarak iki sınıfa ayrılmaktadır. İğne yapraklı ağaçların çam, köknar, sedir ve ladin gibi türleri vardır. Geniş yapraklı ağaçların ise meşe, akçaağaç ve dişbudak gibi türleri vardır (Clemons, 2008).

Odun, ağaç gövdesi boyunca birbirine paralel olarak dizilmiş içi boş, uzatılmış, iğ şeklinde hücrelerden meydana gelir. Lümenler, liflerin içi boş merkezine denir. Lümenlerin içinin tamamı veya bir kısmı reçine, sakız gibi tortularla doldurulabilir. Birbirlerine sıkıca bağlı bu lifler bir araya gelerek odunun yapısını oluştururlar. Odun liflerinin uzunluğu değişkendir. Geniş yapraklı odun liflerinin uzunluğu ortalama $1 \mathrm{~mm}$ iken iğne yapraklı odunlarda ise 3,8 mm'dir (Silvester, 1967).

Odun maddesi; selüloz, hemiselüloz (yarı selüloz) ve ligninden oluşan, üç boyutlu yapısı ile karmaşık polimerik bir kompozittir. Selüloz, odun maddesinin mukavemetini ve yapısal stabilitesini sağlayan ana bileşendir. Selüloz, ağırlıkça \%60-90 oranında kristallidir. Kristal yapısı monoklinik ve triklinik birim hücrelerin karışımından oluşur. Hemiselülozların molekül ağırlığı selülozinkinden düşüktür. 5 ve 6 karbonlu şekerlerden oluşan polimerik hemiselülozlar odunun yapısına katılır. Lignin ise çeşitli hidroksil gruplarının çapraz bağlanarak oluşturduğu düzensiz dizilimli, amorf yapılardaki polimer ağlarıdır. Lignin selüloz lifleri içinde ve arasında kimyasal bir yapıştırıcı görevi görür (Rowell, 1984). Şekil 3’te bir odunun yapısı ile ilgili görsel verilmiştir. 

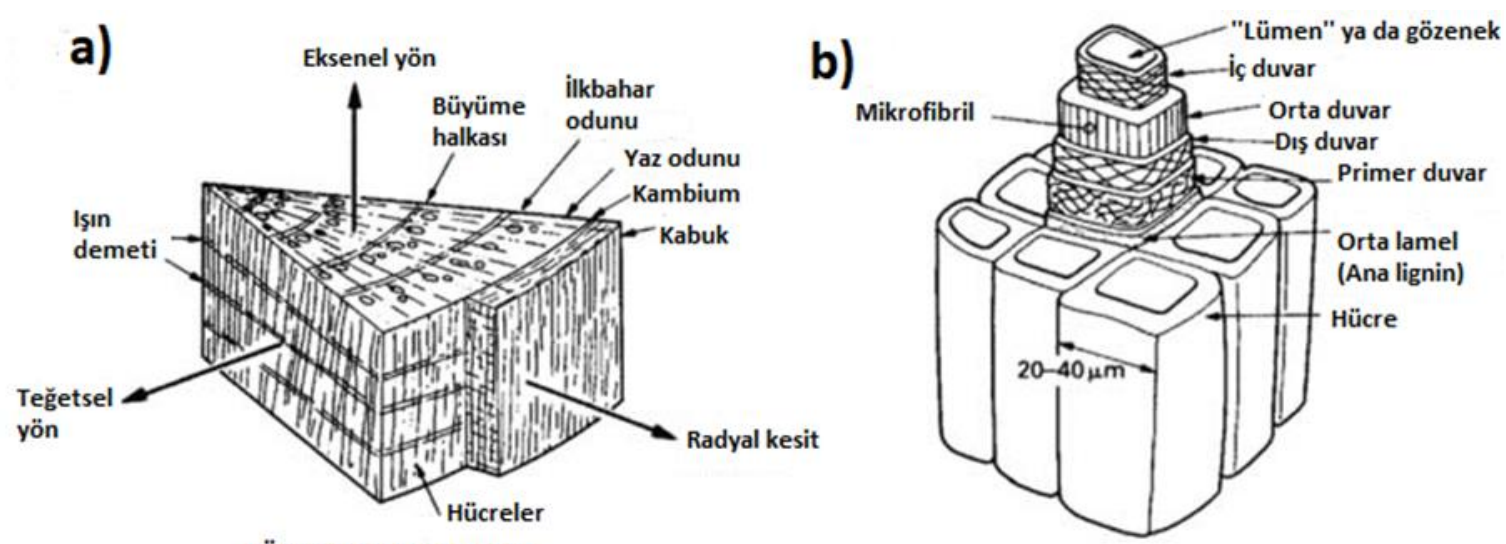

HÜCRE DUVARI KATMANI

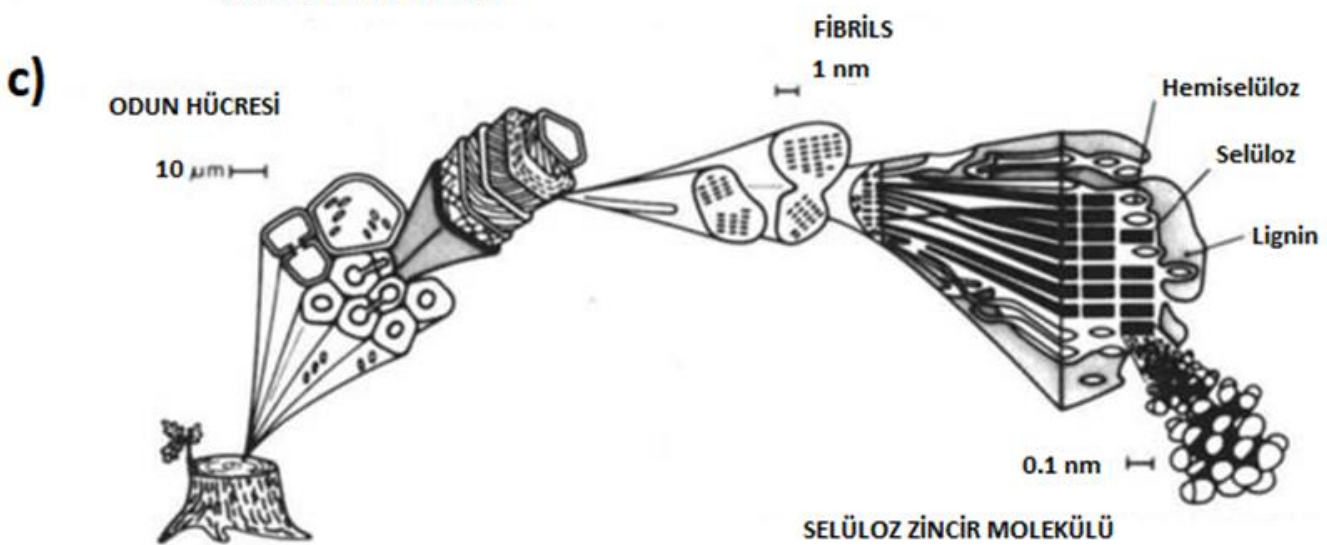

Şekil 3. Odunun tipik yapısı (a) makroskobik kütük seviyesi; (b) mikroskobik hücre seviyesi; (c) moleküler seviyesi (Chan vd., 2018).

Ayrıca, doğal odun liflerinin dolgu malzemesi olarak kullanılabilmesi için işlenip hazır hale getirilmesi gerekir. $\mathrm{Bu}$ nedenle çeşitli iki çeşit odun işleme prosesi kullanılır: öğütme ve hamur haline getirme. Öğütme, taş değirmenler yardımıyla malzemenin kimyasal bileşimleri değiştirilmeden daha küçük parçalara ayrılması işlemidir. Genel olarak kimyasal işlem uygulanmaz. Odun hamuru oluşturma işlemi ise mekanik, kimyasal yollarla malzemenin hamurlaştırılması işlemine dayanır. Şekil 4'te lignoselülozik liflerin üretimi için kullanılan metotlar verilmiştir (Chan vd., 2018).

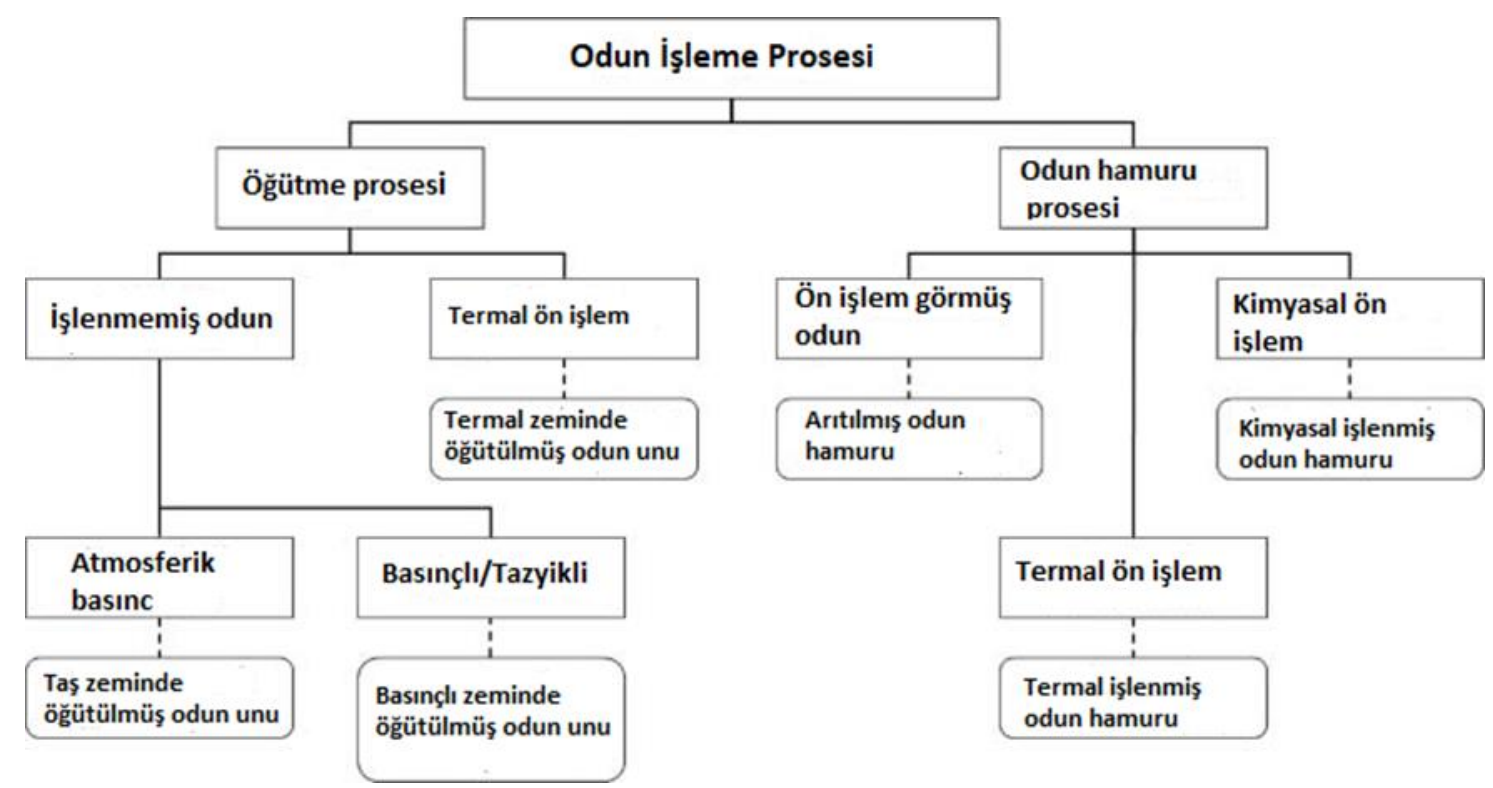

Şekil 4. Lignoselülozik liflerin üretimi için kullanılan işlemler (Chan vd., 2018). 


\section{Polilaktik Asit Polimerinin Özellikleri}

Polilaktit veya polilaktik asit (PLA), laktik asitten üretilen sentetik, alifatik yani benzen halkası içermeyen bir polyesterdir (Riley, 2012). En yaygın olarak kullanılan biyobozunur malzemelerden biridir. PLA, toprakta belirli mikroorganizmaların varlığında hidroliz yoluyla parçalanıp, bozunarak toprağa karışan bir polimer türüdür. Biyobozunur olmasının yanı sıra PLA, biyo bazlı (biyo türevi) olup yenilenebilir bir malzemedir (Koh vd., 2018). Genellikle tarımsal ürünlerden elde edilen termoplastik bir polimerdir. Yaygın olarak kullanılmasının nedeni, biyouyumlu ve biyobozunur olması, nispeten iyi mukavemete sahip olması, kolay bulunabilirliği ve termoplastisite gibi üstün özelliklerdir. PLA polimerinin hazırlanması, laktik asidin doğrudan yoğunlaştırılması veya siklik laktit dimerlerinin halka açıcı polimerizasyonu ile yapılabilir (Elsawy vd., 2017). PLA polimerinin fiziksel, mekanik ve termal özellikleri Tablo 1' de gösterilmiştir.

Tablo 1. PLA polimerinin özellikleri (Madhavan Nampoothiri vd., 2010).

\begin{tabular}{llc}
\hline \multirow{3}{*}{ Fiziksel özellikler } & Erime akış hızı $(\mathrm{g} / 10 \mathrm{dk})$ & $4.3-2.4$ \\
& Yoğunluk $\left(\mathrm{g} / \mathrm{cm}^{3}\right)$ & 1.25 \\
& Bulanılık & 2.2 \\
& Sarılık indeksi & $20-60$ \\
\hline \multirow{3}{*}{ Mekanik özellikler } & Akma sınırındaki gerilme direnci & 53 \\
& $(\mathrm{MPa})$ & $10-100$ \\
& Akma sınırındaki uzama $(\%)$ & $350-450$ \\
& Eğilme katsayısı $(\mathrm{MPa})$ & $350-450$ \\
\hline \multirow{2}{*}{ Termal özellikler } & Cam geçiş sıcaklı̆̆ $\mathrm{Tg}\left({ }^{\circ} \mathrm{C}\right)$ & $55-56$ \\
& Erime noktası $\left({ }^{\circ} \mathrm{C}\right)$ & $120-170$ \\
\hline
\end{tabular}

Ayrıca, PLA glikoz, laktoz, vb. saf maddelerin veya nişasta, melas vb. karbon içeren substratların laktik asit ile anaerobik fermantasyonu sonucu elde edilebilmektedir. PLA, polistirene benzer şekilde şeffaf ve renksiz bir termoplastiktir. Yumuşaklık, erozyon veya aşınma direnci özellikleri iyi ve ultraviyole 1şınlara karşı stabildir. Sağladığı bu avantajlar nedeniyle paketleme endüstrisinde yaygın olarak kullanıldığı görülmektedir (JordáVilaplana vd., 2014).

PLA ilk olarak 1932'de Wallace Hume Carothers isimli Amerikalı bir kimyager tarafından sentezlenmiş, fakat üretim maliyetindeki yükseklik ve son ürün formunun stabilitesi uzun ömürlü olmadığı için başarısız bir buluş olarak görülmüştür. Daha sonra DuPont, 1954 yılında PLA'nın sentez sürecini patentlemiş ve ticari olarak bu polimeri sentezlemeye başlamıştır (Gritsch vd., 2019).

Yılda 140.000 tonu aşan kapasitede üretilebilen doğal kaynaklara dayanan tek termoplastik polimer PLA'dır. Bu nedenle sürdürülebilirlik açısından petrol türevi polimerlerin yerine geçebilecek en umut verici biyopolimerlerden biridir. Petrokimyasal termoplastların fiyatına kıyasla sadece yüksek fiyatı rekabet gücünü düşürmektedir (Bax ve Müssig, 2008). Diğer ticari polimerlere kıyasla PLA üretiminin yararı, karbondioksit $\left(\mathrm{CO}_{2}\right)$ emisyonlarını azaltma avantajıdır. Bu da PLA'nın diğer geleneksel plastiklere kıyasla çevre kirliliğini azaltma potansiyeline sahip olduğunu göstermektedir (Gan ve Chow, 2018).

\section{Odun Kökenli Malzemelerin Takviyesi İle Oluşturulan Polilaktik Asit Matrisli Kompozitler}

Odun liflerle güçlendirilmiş plastik kompozitler, odun unu ve termoplastik reçinelerin kombinasyonundan yapılmış yeni bir malzeme grubudur. Odun unu takviyeli kompozitlerin, mobilya, otomotiv ve inşaat endüstrilerinde kullanımı giderek daha popüler hale gelmektedir. Bu kompozitlerde en çok tercih edilen biyobozunur polimerlerden biri olan PLA'dır. PLA ve Odun unu içeren biyobozunur kompozitler, düşük maliyetin yanı sıra üstün mekanik özellikler sergilerler (Huda vd., 2006). Odun-polimer kompozitlerin sergiledikleri bu özellikler, düşük nem tutma, düşük yoğunluk, darbelere karşı gösterdiği yüksek direnç, iyi boyutsal kararlılık ve yüksek mukavemet olarak sıralanabilir (Dalu vd., 2019). PLA'nın daha geniş uygulamaları kırılganlık ve düşük termal direnç gibi dezavantajları nedeniyle sınırlı olduğundan, bu dezavantajların üstesinden gelmek için, odun kökenli doğal lifler PLA polimeri için takviye malzemesi olarak kullanılmaktadır. Bu sayede PLA'nın çok sayıda özelliklerini istenilen seviyelerde iyileştirmek mümkündür. Bu nedenle, odun kökenli doğal elyaflarla takviye edilmiş PLA kompozitler, sergiledikleri spesifik mekanik özelliklerin yanı sıra uygun kullanım ömrü yönetimi ve çevre dostu olması nedeniyle giderek daha çekici hale gelmiştir (Yang, 2018). Ayrıca, PLA matrisli odun lifi 
takviyeli oluşturulan kompozit malzemeler, elde edilen yeni kompozit malzemenin mekanik özelliklerini geliştirmektedir (Le Duigou vd., 2016). Genel olarak içerdikleri farklı odun lif/un oranları ile mekanik özellikleri, çekme modülü ve çekme mukavemeti gibi özellikler artış göstermektedir (Huda vd., 2006).

\section{7.Üretim Teknikleri}

Genel olarak PLA-odun biyo-polimerlerin üretimi için, karıştırma döküm, enjeksiyon kalıplama, ekstrüzyon ve sıkıştırma kalıplama olmak üzere dört farklı yöntem kullanılmaktadır.

\subsection{Ekstrüzyon metodu}

Ekstrüzyon metodu çoğunlukla istenen vida hızına ve sıcaklığına ayarlanmış vidalı ekstrüder sistemi kullanılarak yapılmaktadır (Adeniyi vd., 2019). Ekstrüzyon, toz, granüller veya eriyik formundaki polimerik malzemelerin sürekli bir şekilde, kontrollü kesitli ürünlere dönüştürüldüğü üretim yöntemidir. Malzemenin 1sı veya basınç yardımıyla plastikleştirilmesi, plastikleştirilen malzemenin ekstrüder içinden geçirilip soğutularak istenen kesitlerde üretim yapılması işlemidir. Son yıllarda lif takviyeli polimer kompozitlerin üretiminde yaygın olarak kullanılmaktadır (Muley vd., 2016). Şekil 5'te ekstrüzyon üretim metodu gösterilmiştir.

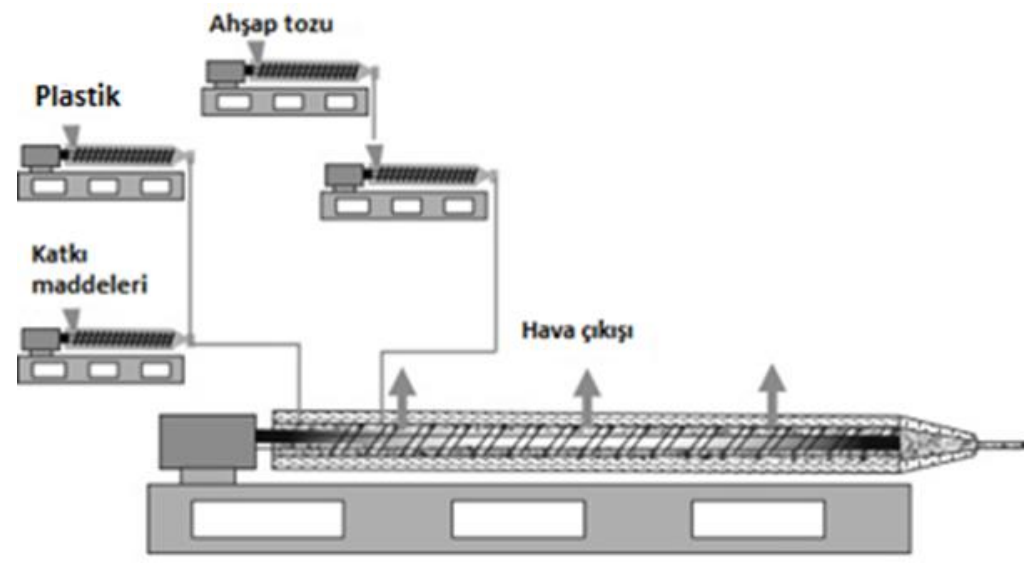

\subsection{Enjeksiyon kalıplama}

Şekil 5. Ekstrüzyon üretim metodu (Cogswell ve Leach, 1986).

$\mathrm{Bu}$ kalıplama işlemi yaygın olarak kısa elyaflar, elyaf parçacıkları veya toz ile takviye edilmiş polimer kompozitlerin imalatında kullanılmaktadır. Çift vidalı bir ekstrüder kullanarak granül formlu kompozitin hazırlanmasını (karıştırmasını) içerir. Granüller, ısıtma işlemi vidanın kesme hareketi ile birleştirilen bir besleme hunisi ve 1sıtılmış bir varil kullanılarak bir kalıbın içine beslenir. Erimiş kompozitler kalıbın şeklini alır ve istenen kompozit parçayı oluşturmak üzere sertleşmesine izin verilir. Enjeksiyon kalıplama, elyafın reçinedeki dağılımını iyileştirir, böylece kompozitlerin gerilme ve bükülme özelliklerini geliştirir (Adeniyi vd., 2019). Şekil 6'da enjeksiyon kalıplama metodu gösterilmiştir. 


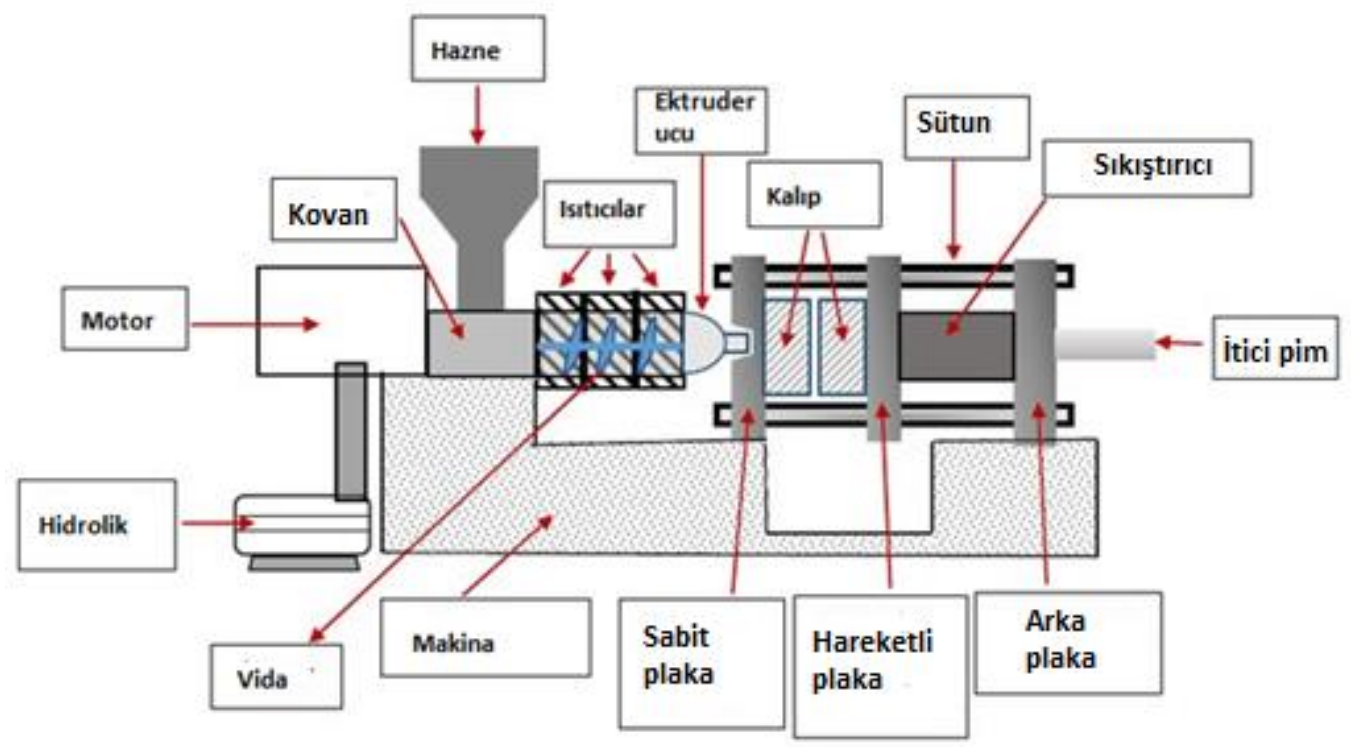

Şekil 6. Enjeksiyon kalıplama metodu (Maged vd., 2019).

\subsection{Sıkıştırma kalıplama}

Pres kalıplama yönteminin termal iletken dolguların dağılımının kontrol edilebilmesi açısından avantajları bulunmaktadır. Erimiş polimerin, bitişik termal olarak iletken dolgu maddeleri arasında mikro kanallara tam olarak sızmasını sağlamak ve sürekli polimer faz akışı oluşturmak için kalıplama yöntemini kullanır. Aynı zamanda, termal olarak iletken dolgu maddeleri de termal iletim yolları oluşturur (Guo vd., 2020). Şekil 7'de sıkıştırma kalıplama metodu gösterilmiştir.

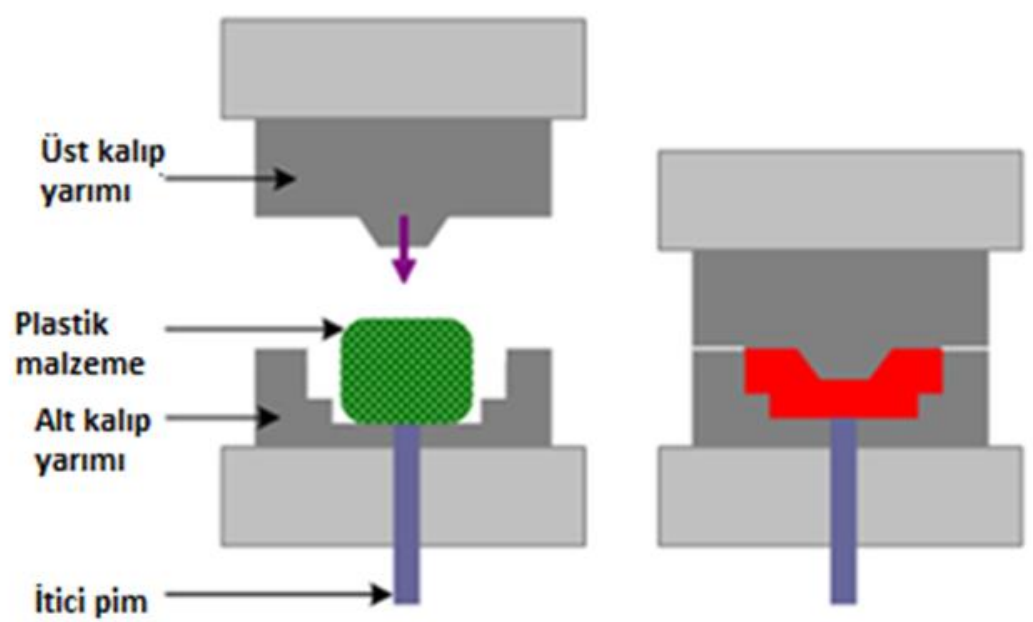

Şekil 7. Sıkıştırma kalıplama metodu (Han vd., 2012).

\subsection{Karıştırma döküm metodu}

Döküm, polimer çözeltilerinin, eriyiklerin, dispersiyonların işlenmesinde yaygın olarak kullanılmaktadır (Guo vd., 2020). Polimer çözeltisi döküm işlemi, işlem için özel olarak tasarlanmış bir polimer çözeltisi veya sıvı plastik tankına daldırılmış bir mandrel veya iç çaplı bir kalıp kullanılarak yapılmaktadır. Metot, bir polimerin bir veya bir çözücü karışımında çözündürülmesi, çözeltinin uygun bir kalıba aktarılması ve çözücünün tamamen buharlaşana kadar sabit bir sıcaklıkta inkübe edilmesinden oluşur (Calori vd., 2020). Şekil 8'de karıştırma döküm 
metodu gösterilmiştir.

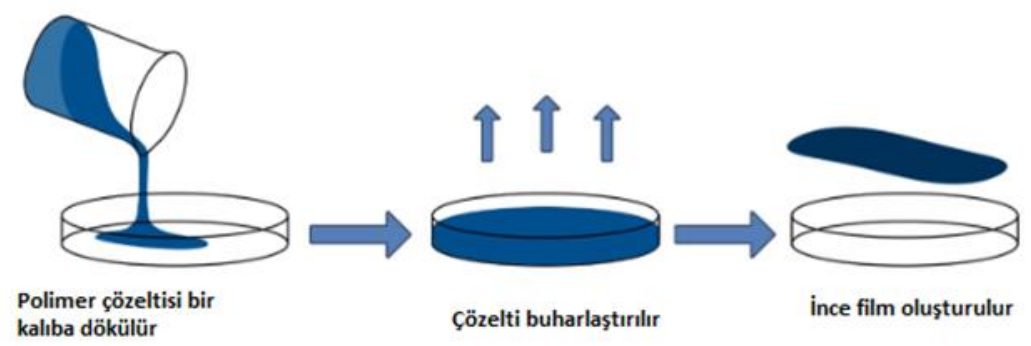

Şekil 8. Karıştırma döküm metodu (Calori vd., 2020).

\section{Literatürde Yapılan Çalışmalar}

Son y1llarda, PLA matrisli odun kökenli takviye kompozitler üzerine ulusal ve uluslararası literatürde birçok çalışma yapılmıştır. Elde edilen odun polimer kompozitlerin hem mekanik (mukavemet, sertlik, süneklik gibi) hem de mikro yapılarının geliştirilmesi için farklı üretim yöntemleri kullanılarak çalışmalar yapılmıştır (Teuber vd., 2016). Tao vd. PLA matrisine ağırlıkça \%5 oranında odun unu ekleyerek, bu kompozitlerden 3 boyutlu FDM (Fused Deposition Modelling) yazıcı tipi için filamentler üretmiş̧lerdir. Elde edilen yeni odun PLA kompozit filamentler, saf PLA filamentler ile kıyaslandığında, odun unlarının, filamentlerin yüzeyinin mikro yapısını değiştirdiği ve deformasyon direncini arttırdığı gözlenmiştir. Fakat, termal bozunma sıcaklığının çok az miktarda düştüğü, erime sıcaklığı üzerine ise herhangi bir etkisi olmadığı belirlenmiştir (Tao vd., 2017). Diğger yandan, 3 boyutlu yazıcılarda kullanmak üzere odun unu takviyeli PLA matrisli kompozitler hazırlanarak, bu numunelerin baskı katmanları üzerinde yüzey pürüzlülüğü ve ıslanabilirliği etkisi üzerine çalıșılmıştır (Ayrilmis, 2018). PLA matrisine ağırlıkça \%30 odun lifi ilavesiyle eğilme modülü $8.9 \mathrm{GPa}$ bulunmuş ve odun liflerinin PLA matrisi içerisine dahil edilmesi ile kompozit malzemenin sertlik özelliğinde artış sağlamıştır (Huda vd., 2006).

Bazı çalışmalarda, PLA ile odun lifleri arasındaki zayıf ara yüz yapışmasını iyileştirmek için ara ajanlar kullanılmış ve etkileri gözlenmiştir. Bunlardan, N, N-(1,3-fenilen dimaleimid) (BMI) ve 1,1 (metilenedi-4,1fenilen) bismaleimid (DBMI) olmak üzere iki reaktif kaplin maddesi örnek verilebilir. İki bileşen ile hazırlanan kompozit malzemelerin sertlik, mukavemet ve dayanımları geliştirdiği görülmektedir. Fakat DBMI'nin BMI'den daha iyi etki gösterdiğinin altı çizilmiştir (Faludi vd., 2013). PLA'nın hem işlenebilirliğini arttırmak hem de mekanik özelliklerini geliştirmek için ağırlıkça \%40 odun lifi takviyeli PLA kompozitlerinde uygulama için fonksiyonel bir mineral katkı maddesi olarak ağırlıkça sırasıyla \%10, \%20, \%30 alkenil süksinik anhidrit yüzey işlem görmüş kalsiyum karbonat kullanılmaktadır (Ozyhar vd., 2020). Kavak ağacı tozu ve PLA kompozitlere termoplastik poliüretan (PU), polikaprolakton (PCL) gibi sertleştirici ajanlar eklenerek kaynaştırılmış ve tokluk ve ara yüz özellikleri geliştirilmeye çalışılmıştır. Termoplastik PU ilavesi ile darbe dayanımı $\% 51,3$ oranında artmıştır (R. Guo vd., 2018). PLA matrisine takviye edilen odun unu parçacıklarının emprenye edilebilmesi için $\% 1$ 'lik resol tipi fenolik bir bileşik kullanılmıştır. Sonuç olarak, kompozitin su emilimi \%17'den \%6 ya düşmüş ve çekme dayanımı önemli ölçüde artmıştır PLA odun lifi takviyeli polimerleri oluşturmak için odun unu Tanalit E (Pinus sylestris L.) ile işlenmiş ve PLA matrisine takviye edilmiştir. Ağırlıkça \%40 oranında işlenmiş odun lifi oluşturulan kompozitlerin normal işlenmemiş PLA-odun lifi polimerlere karşın yoğunluklarının arttığı ve mekanik özelliklerinin geliştirildiği gözlenmiştir (Dalu vd., 2019). PLA ile selüloz kompozitleri arasındaki yapışmayı iyileştirmek için stearoil klorür kullanılmıştır. Selülozlar stearoil klorür ile enzimatik olarak modifiye edilmiş ve modifiye edilmiş selülozlar hazırlanan kompozitlerin normal selülozla hazırlanan kompozitlere karşın sertlik özelliklerinde \%22 den \%26'ya yükseldiği görülmüştür (Spiridon vd., 2016). Bir başka çalışmada odun unu takviyesine ek olarak kitosan bağlayıcı ajan olarak PLA matrisine eklenmiş ve PLA matrisinde meydana gelen mekanik, kimyasal ve termal özellikler incelenmiştir. Kitosanın bu çalışmada PLA'nın mekanik, kimyasal ve termal özellikleri üzerine kayda değer bir etkisi olmadığı gözlenmiştir (Shah vd., 2008). Kırılgan PLA kompozitlerini sertleştirmek için, yüzeyi ağırlıkça \%1 ila \%16 arasında belirlenen konsantrasyonlarda (3merkaptopropil) trimetoksisilan (A-189) modifiye edilmiş bambudan elde edilen selüloz nanokristaller PLA matrisine eklenmiştir. Sonuç olarak, PLA matrisine ağıllıkça \%4 A-189 ile muamele görmüş selüloz nanokristallerin eklenmesi ile kopma uzaması $\% 12,35$ den \%250,8 yükseldiği gözlenmiştir (Qian ve Sheng, 2017). Sitka ladin ağacından elde edilen hidrofilik lifler ve hidrofobik polimer matrisi arasındaki ara yüz uyumluluğunu arttırmak için, lifler viniltrimetoksisi ane (VTMO) ile PLA ise 4,4-metilen difenil diizosiyanat (MDI) ile muamele görmüştür. VTMO ve MDI ile muamele edilen PLA / Sitka lif kompozitlerin, gelişmiş termal ve mekanik özellikler sergilediği gözlenmiştir (Gregorova vd., 2009). PLA ve Polihidroksibütirat (PHB) 
polimerine nanolif ve nanokillerin takviyesi ile hazırlanan kompozitlere nanoboron nitrür ilavesi ile mekanik özelliklerde meydana gelen değişikler incelenmiş ve çekme modülü dışındaki özelliklerin azaldığı gözlenmiştir (Al vd., 2018). Maleik anhidrit greftpolipropilenin (MA-g-PP) bir uyumlaştırıcı ajan olarak, PLA ve polipropilen (PP) polimer matrisine odun lifi takviyesi ile oluşturulan kompozitlere dahil edilmiştir. MA-g-PP uyumlaştırıcı ilavesiyle elde edilen kompozitlerin çekme modülü ve izot darbe mukavemeti dışındaki mekanik özellikleri geliştirdiği gözlenmiştir (Altuntas vd., 2018). Farklı bir çalışmada, PLA-odun lifi kompozitlerinin mekanik özelliklerini geliştirmek için 3 tane silan bağlayıcı ajanı kullanılmıştır. Elde edilen kompozit malzemelerin çekme mukavemeti ve Young modülü sırasıyla 55.1 ve1589 MPa'dan 67 ve 1641 MPa kadar arttı̆̆ı gözlenmiştir. Ayrıca, kopma uzamasının \%20,3'ten \%12,4'e düştüğü gözlenmiştir (Zhu vd., 2015). PLA matrisine geri dönüştürülmüş silan ile muamele edilmiş karbon fiberler takviye edilerek kompozitler oluşturulmuştur. Silanın PLA ve karbon fiberler arasında ara yüzey yapışmasını arttırdığı gözlenmiştir (Han vd., 2012).

PLA polimerine odun kökenli takviye elemanlarının yanı sıra diğer polimerler de eklenerek kullanılmıştır. Alvarado vd. timol gibi antimikrobiyel bir ajanı PLA ve Polivinil alkol (PV) polimerine ağırlıkça \%4,7 nanoselüloz takviyesi içeren kompozite ilave etmiştir. \%20 ile \%24 aralığında dahil edilen timolun kompozitin mekanik özelliklerini geliştirdiği belirtilmiştir (Alvarado vd., 2018). Polibütilen süksinat (PBS) /PLA polimer karışımına odun unu ilavesiyle elde edilen kompozitlerlerin zayıf ıslanabilirlik ve ara yüzey yapışma özellikleri nedeniyle uyumlu olmadığı görülmüş ve bu durumu çözümleyebilmek için karışıma FUSABOND MB 100 D (FB) ajanı eklenerek ara yüzey bağının iyileştirilmesi hedeflenmiştir. Sonuç olarak, FB'NİN eklenmesi ile hem çekme mukavemeti hem de darbe mukavemeti artmıştır (Saeed vd., 2018). PLA/Polihidroksialkanoat (PHA) karışım matrisine \%40 odun lifi takviye edilerek katmanlı imalat için filament üretimi yapılmış ve elde edilen numunelerde yaklaşık \%20 kadar mikro gözenekli yapıların olduğu gözlenmiştir (Le Duigou vd., 2016). PLA/PHA polimer matrisine ağırlıç̧a 10\%, 20\%, 30\% odun lifi takviye edilerek oluşturulan kompozitlerin mekanik özellikleri karşılaştırılmış ve ağırlıkça \%20 odun lifi takviyesinin en iyi olduğu sonucu gözlenmiştir. Ayrıca polimer matrisi içerisinde ağırlıkça \%20 odun lifi içeren kompozitin en iyi homojen dağılımı gösterdiği gözlenmiştir (Loureiro vd., 2014). Ağırlıkça \%30 odun lifi takviyeli PLA kompozitlerde, geleneksel odun lifi takviyeli PP kompozitlere karşın eğilme modülünün 3.4 GPa'dan $8.9 \mathrm{GPa}$ yükseldiği gözlenmiştir (Huda vd., 2006).

Selülozlar bazı çalışmalarda, mikro veya nano boyutlarda takviye elemanı olarak kullanılmıştır. 3 boyutlu yazıcılarda baskı için kullanılacak filamentlerin üretiminde, ağırlıkça \%30 mikro selüloz takviyeli PLA matrisli kompozitler oluşturulmuştur. Elde edilen bu ürünlerin saf PLA kompozitlerine karşın kopma uzaması \% 12 artmış, gerilme mukavemeti 59.7 MPa, eğilme mukavemeti ise 50.7 MPa olarak ölçülmüştür (Wang vd., 2017). Odun kökenli mikro selülozlardan nanoselülozlar elde edilerek, ağırlıkça \%5 oranında bu nanoselülozlar karıştırma döküm yöntemi ile PLA matrisine ilave edilmiştir. Bu sayede, üretilen yeni kompozitlerin cam geçiş sıcaklığ1, erime sıcaklığg, kristallik derecesi ve termal ayrışma gibi termal özellikleri geliştirilmiştir (Khoo vd., 2016). Mekanik özelliklerinin karşılaştırılması amacıyla PLA matrisine homojen olarak dağılmış selüloz ve nanoselülozdan oluşan iki farklı kompozit malzeme hazırlanmıştır. Nanoselüloz içeren polimer kompozitin selüloz içeren kompozite karşın akma dayanımını \%50 arttırdığı gözlenmiştir (Kowalczyk vd., 2011). Ekstrüzyon bazlı 3 boyutlu yazıcılarla üretilen ürünlerin kristalliğini ve mekanik performansını geliştirmek amacıyla, PLA matrisine karbonize edilmiş selüloz nanofiberler takviye edilmiştir. Bu nedenle bu çalışmada mikrodalga tavlama yöntemi kullanılmıştır. Sonuç olarak, soğuk kristalleştirme sıcaklığının altında gerçekleştirilen mikrodalga tavlamanın, 3D baskılı PLA kompozit üretimi için optimize edilmiş bir kristallik ve gerilme mukavemeti geliştirmek için son derece elverişli olduğu gözlenmiştir (Dong vd., 2020). Bir çalışmada PLA matrisine mikrokristalin selüloz ve selüloz nanokristal takviye edilerek etkileri karşılaştırılmıştır. Hem mikrokristalin selüloz hem de selüloz nanokristal takviye elemanları ağırlıç̧a \%3, 5 ve 7 oranlarında PLA matrisine ayrı ayrı eklenerek kompozitler hazırlanmıştır. Ayrıca, bazı bileşimlere takviye elamanına ek olarak, selüloz matris uyumluluğunu geliştirmek için organofilik silika (R972) ilave edilmiştir. Selüloz nanokristal içeren kompozitlerin mikrokristalin selüloz içeren kompozitlere oranla PLA polimeri ile daha iyi ara yüz etkileşiminde olduğu gözlenmiş ve R972'nin iyi bir uyumlulaştırıcı ara ajan görevi sergilediği gözlenmiştir (dos Santos vd., 2017). Ambalaj endüstrisinde kullanımı için PLA matrisine takviye olarak modifikasyona uğramış selüloz nanokristaller eklenmiştir. Sonuç olarak, \%5 oranında modifiye edilmiş selüloz nanokristallerin modifiye edilmemiş nanokristallere oranla Young modülünü arttırmıştır (Wei vd., 2016). PLA polimer matrisinin kristalleşmesi üzerindeki etkisini incelemek için PLA matrisine takviye elamanları olarak sırasıyla ağırlıkça \%25 oranında sırasıyla mikrokristalin selüloz, selüloz lifi ve odun unu eklenmiştir. Elde edilen kompozitler karşılaştırıldığında kristalleşme yüzdeleri, mikro kristal selüloz 56.5, odun unu 52.5 selüloz lifi ise 53,4 olarak ölçülmüş ve mikrokristalin selülozun PLA polimeri ile oluşturulan kompozitin daha yüksek kristalleşme özelliği gösterdiği gözlenmiştir (Mathew vd., 2006).

Lignin içeriğinin PLA polimeri üzerinde bozunma süresini etkilediğini gözlemlemek için PLA matrisine ağırlıç̧a $\% 5, \% 10$ ve $\% 15$ oranlarında Kraft lignini eklenmiştir ve \%10 oranında lignin ilavesinin biyolojik olarak parçalanabilir paket endüstrisinde kullanımının uygun olduğu görülmüştür (Silva vd., 2019). Yüksek lignin içerikli selülozlarla hazırlanan PLA matrisli kompozitler, daha yüksek kristallik, daha az topaklanma ve 
hidrofobik yüzeyler sergilemiştir. Ayrıca, Young modülü \%14,77 ve kopma uzamas1 \%30 oranında iyileştirilmiştir (Wei vd., 2018).

Pickering Emülsiyon yöntemi ile kristal nanoselülozların PLA matrisi içerisinde homojen dağılımı sağlanmaya çalışılmış ve bu yöntemle hazırlanan kompozitler ağırlıkça \%5 kristal nanoselülozlar içermektedir. Bu şekilde emülsiyon yöntemi ile hazırlanan kompozitlerin kristal nanoselülozların dağılımı üzerinde olumlu etkileri olduğu gözlenmiştir (Zhang vd., 2019). Benzer şekilde, Pickering emülsiyon yöntemi ile hazırlanan ağırlıça \%5, \%10, \%15 nanoselüloz içeren PLA matrisli kompozitler hazırlanmış ve kompozitlerin bozulması için Candida rugosa'dan lipaz ve tritirachium albümünden proteinaz K ile katalize edilmiştir. Sonuç olarak, Candida rugosa'dan alınan lipazın PLA'nın bozulmasını etki etmediğini, ancak proteinaz K'nin çok etkili olduğu belirtilmiştir (Hegyesi vd., 2019).

PLA-odun polimer kompozitlerin elde edilmesinde üretim metotları önemli bir rol oynar ve bu metotlarla ilgili yapılan birçok çalışma vardır. Örnek verecek olursak, Raj vd. ağırlıkça \%20 odun unu takviyeli PLA matrisli kompozitlerin üretimi için ekstrüzyon, enjeksiyon, karıştırma döküm ve sıkıştırma kalıplama metotlarının hepsini kullanmıştır. Farklı tekniklerle elde edilen kompozitlerde yapılan karşılaştırmada mekanik özellikleri geliştiren en iyi tekniğin enjeksiyon kalıplama metodu olduğu söylenmiștir (Raj vd., 2020). Enjeksiyon kalıplama yöntemi kullanılarak üretilen odun unu ve PLA kompozitinin mekanik özelliklerini iyileştirmek için talk dolgu malzemesi ve silan kullanımı da mümkündür. Ağırlıkça \%1 talk ve silanın PLA- odun unu kompozitlerin çekme direnci modülünü geliştirdiği belirtilmektedir (Lee vd., 2008). PLA/(PBS) matrisine ağırlıkça 5\%, 10\%, 15\%, 20\%, 30\% odun unu ilave edilerek ekstrüzyon metodu ile üretim yapılmıştır. Elde edilen kompozitler karşılaştırıldığında \%15 odun unu içeren ürünün en iyi biyobozunurluk özelliğine sahip olduğu gözlenmiştir (Chuayjuljit vd., 2017). Bazı çalışmalarda ekstrüzyon ve enjeksiyon metodu birlikte kullanılmıştır. Ektrüzyon ve enjeksiyon kalıplama metotları kullanılarak, ağırlıkça \%5 oranında nanoselüloz içeren PLA matrisli kompozitler hazırlanabilir. Nanoselülozların eklenmesi ile PLA'nın kristalleşme davranışında \%25'ten \%75'e kadar iyileşmeler olduğu gözlenmiştir (Perić vd., 2019). Tablo 2'de kullanılan matris malzemesi, takviye elemanları ve oranları ve üretim teknikleri ile ilgili yapılan bazı çalışmalar verilmiştir.

Tablo 2. Odun-PLA kompozitlerin takviye elamanları, oranları ve üretim metotları

\begin{tabular}{|c|c|c|c|c|}
\hline Matris & Takviye elemanı & $\begin{array}{l}\text { Oranlar } \\
\text { Wt \% } \\
\text { /Vol\% }\end{array}$ & Üretim teknikleri & Kaynaklar \\
\hline PLA/PBS & Odun unu & $5-30 \mathrm{wt} \%$ & Ekstrüzyon metodu & (Chuayjuljit $v d ., 2017$ ) \\
\hline PLA & $\begin{array}{l}\text { Odun unu } \\
\text { Maleik anhidrit aşılanmış } \\
\text { polietilen (MAPE) } \\
\text { Tanalith E }\end{array}$ & $\begin{array}{l}30,40 \mathrm{wt} \% \\
3 \mathrm{wt} \%\end{array}$ & Ekstrüzyon metodu & (Dalu vd., 2019) \\
\hline & & $3 \mathrm{wt} \%$ & & \\
\hline PLA/PHA & Selüloz lifi & $0-30 \mathrm{wt} \%$ & Ekstrüzyon metodu & (Loureiro vd., 2014) \\
\hline PLA & $\begin{array}{l}\text { Yüksek lignin içerikli } \\
\text { selüloz nanokristal }\end{array}$ & $0.5-5 \mathrm{wt} \%$ & Enjeksiyon metodu & (Wei vd., 2018) \\
\hline PLA & $\begin{array}{l}\text { Odun lifi } \\
\text { Alkenil süksinik anhidrit } \\
\text { (ASA) -yüzey işlem } \\
\text { görmüs kalsiyum karbonat }\end{array}$ & $\begin{array}{l}40 \mathrm{wt} \% \\
0-20 \mathrm{wt} \%\end{array}$ & Enjeksiyon metodu & (Ozyhar vd., 2020b) \\
\hline PLA & Selüloz nanokristal & $3-7 \mathrm{wt} \%$ & $\begin{array}{l}\text { Karıştırma döküm } \\
\text { metodu }\end{array}$ & (dos Santos vd., 2017) \\
\hline PLA & Keten Selüloz nanolifler & $2.5,5 \mathrm{wt} \%$ & $\begin{array}{l}\text { Karıştırma döküm } \\
\text { metodu }\end{array}$ & (Liu $v d ., 2010)$ \\
\hline PLA & Kraft lignin & $0-15 \mathrm{wt} \%$ & Sıkıştırma kalıplama & (Silva $v d ., 2019)$ \\
\hline PLA & $\begin{array}{l}\text { Bambu selüloz nanokristal } \\
\text { Silan }\end{array}$ & $2.5 \mathrm{wt} \%$ & Sıkıştırma kalıplama & (Qian ve Sheng, 2017) \\
\hline
\end{tabular}

\section{Uygulama Alanları}

Odun unu dolgulu PLA matrisli kompozitler sağladığı büyük avantajlar nedeniyle endüstride birçok uygulama 
alanı bulmuştur. Bu polimer kompozitleri uygulama alanları genel olarak dört kategoride toplanır. Bunlar: inşaat, trafik, askeri ve mobilya malzemeleridir ( $\mathrm{Li}, 2011)$. Ayrıca, yeni nesil mühendislik malzemelerinin üretiminde, otomotiv (Liu vd., 2010), inşaat ve deniz gibi endüstrilerde kullanımı yaygınlaşmıştır (Ashori, 2008). Mekanik özelliklerinin geliştirilmiş daha dayanıklı malzemeler olduğundan, zemin kaplaması, eskrim, elektrik direkleri ve binalarda dış cephe ve dış mekân uygulamalarında odun yapılı polimerlerin kullanımı önemli bir artış göstermiştir. Odun polimer kompozitler aynı zamanda diğer, geleneksel kompozitlerden daha sürdürülebilir olduğundan, normal odun malzemeyle elde edilemeyen kalitede ürünler elde edilebilmektedir. (Li, 2011). Şekil 9'da odun polimer kompozitlerin kullanım alanları ile ilgili görseller verilmiştir.

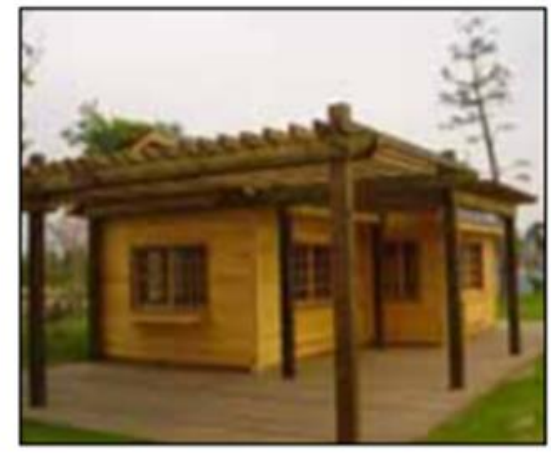

(a)

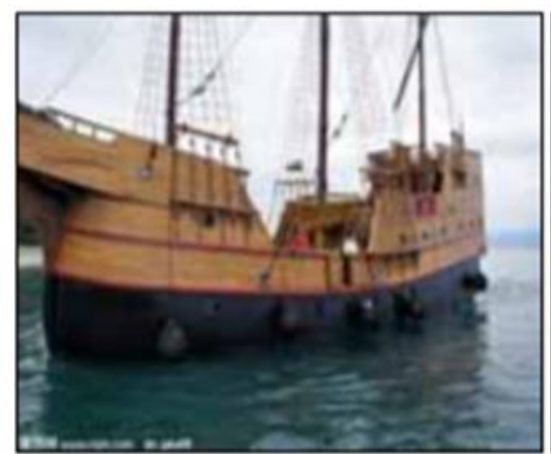

(d)

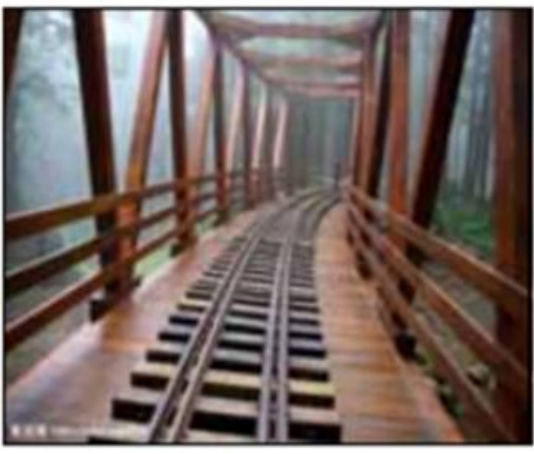

(b)

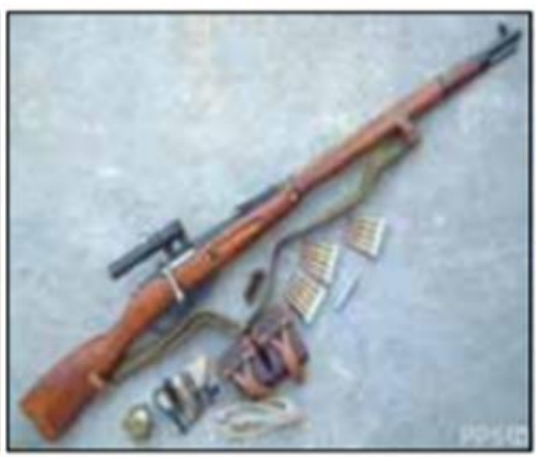

(e)

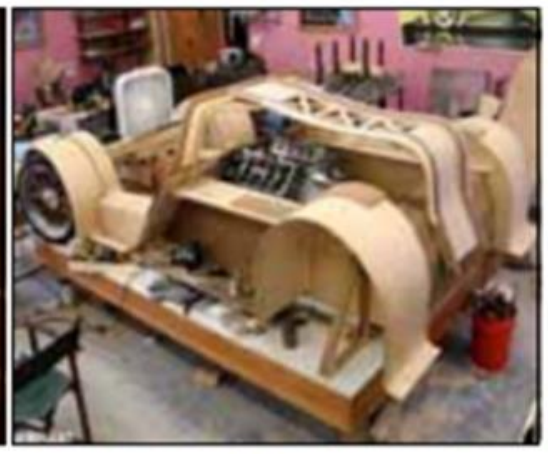

(c)

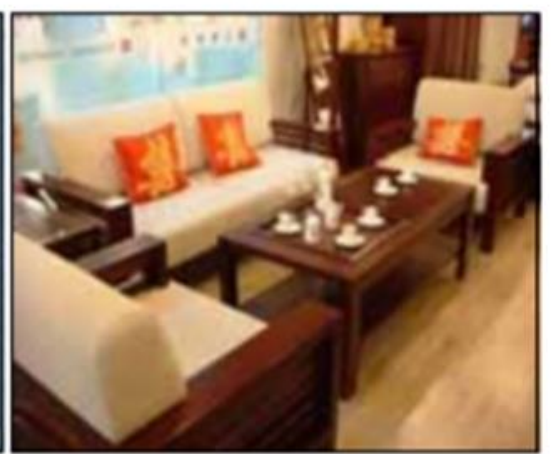

$(\mathrm{f})$

Şekil 9. Odun polimer kompozitlerin kullanım alanları (a) İnşaat malzemesi (b) Trafik malzemesi c) Arabalı yatak modeli için destek malzemesi A(d) Gemi malzemesi (e) Askeri malzemeler (f) Mobilya malzemeleri (Li, 2011).

\section{Sonuç ve Öneriler}

$\mathrm{Bu}$ derlemede, son 10 yılda yapılan odun kökenli takviye elemanlarının PLA polimer matrisine eklenmesi ile elde edilen yeni kompozit malzemelerin özelliklerini araştırmak için yapılan çalışmalar incelenmiştir. Yapılan çalışmalarda kullanılan takviye elamanları ve oranlarının, elde edilen yeni kompozitlerin mekanik özelliklerinde genel olarak olumlu yönde meydana getirdiği değişimler incelenerek belirtilmiştir. Ayrıca polimer matrisli kompozitlerin üretim tekniklerinde, malzemenin özellikleri üzerine etkileri olduğu görülmüştür. Sonuç olarak, odun kökenli kompozitlerin PLA matrisi için dolgu maddesi olarak kullanılması, düşük maliyet, düşük yoğunluk, yüksek özgül mukavemeti ve geleneksel inorganik dolgu maddelerine kıyasla işleme ekipmanlarına daha az olması nedeniyle birçok avantaj sağladığı yapılan araştırmalar neticesinde anlaşılmıştır. Ayrıca, yapılan birçok çalışmada sertlik, mukavemet, tokluk, boyutsal kararlılık ve aşınma, çürüme, hava ve yangına karşı dirençli olması gibi özelliklerin de geliştirildiği gözlenmiştir.

Yapılan çalışmalarda PLA matrisine odun kökenli takviye malzemesi olarak odun unu, odun lifi, mikro selüloz ve nanoselüloz kullanılmış ve eklenen takviye elemanlardan nanoselüloz PLA matrisi içerisinde en iyi homojen dağılım göstermiştir. Ayrıca, PLA matrisine ağırlıkça \%40’a kadar odun lifi eklenerek mekanik özellikler iyileştirilebilirken, nanoselüloz takviyeli kompozitlerde ise PLA matrisine yaklaşık olarak ağırlıkça \%5 nanoselüloz takviyesi yeterli olmaktadır. Bununla birlikte, PLA-odun kompozitlerin ara yüz yapışmasını 
iyileştirebilmek için kullanılan çok fazla bağlayıcı olmasına karşın, en etkili olarak gözlenen silan kimyasalı olmuştur. Diğer yandan, üretim tekniklerinin kompozitlerin mekanik özellikleri üzerindeki etkileri düşünüldüğünde ise en iyi metodun enjeksiyon kalıplama metodu olduğu söylenebilir.

\section{Kaynaklar}

1. Adeniyi, A. G., Onifade, D. V., Ighalo, J. O., Adeoye, A. S. (2019). A review of coir fiber reinforced polymer composites. Composites Part B: Engineering, 176(August), 107305.

2. Al, G., Aydemir, D., Ayrilmis, N., Kaygin, B., Gunduz, G. (2018). Učinak nanočestica boron-nitrida na neka svojstva biopolimernih nanokompozita s celuloznim nanovlaknima i nanočesticama gline. Drvna Industrija, 69(1), 43-48.

3. Altuntas, E., Salan, T., Karaogul, E., Aydemir, D. (2018). Effects of MA-g-PP and lignocellulosic filler addition on several properties of poly(L-lactic acid)/polypropylene composites. International Journal of Polymer Analysis and Characterization, 23(1), 89-98.

4. Alvarado, N., Romero, J., Torres, A., López de Dicastillo, C., Rojas, A., Galotto, M. J., Guarda, A. (2018). Supercritical impregnation of thymol in poly(lactic acid) filled with electrospun poly(vinyl alcohol)cellulose nanocrystals nanofibers: Development an active food packaging material. Journal of Food Engineering, 217, 1-10.

5. Ashori, A. (2008). Wood-plastic composites as promising green-composites for automotive industries! Bioresource Technology, 99(11), 4661-4667.

6. Averous, L., Boquillon, N. (2004). Biocomposites based on plasticized starch: Thermal and mechanical behaviours. Carbohydrate Polymers, 56(2), 111-122.

7. Ayrilmis, N. (2018). Effect of layer thickness on surface properties of 3D printed materials produced from wood flour/PLA filament. Polymer Testing, 71(July), 163-166.

8. Balla, V. K., Kate, K. H., Satyavolu, J., Singh, P., Tadimeti, J. G. D. (2019). Additive manufacturing of natural fiber reinforced polymer composites: Processing and prospects. Composites Part B: Engineering, 174(May), 106956.

9. Bax, B., Müssig, J. (2008). Impact and tensile properties of PLA/Cordenka and PLA/flax composites. Composites Science and Technology, 68(7-8), 1601-1607.

10. Calori, I. R., Braga, G., de Jesus, P. da C. C., Bi, H., Tedesco, A. C. (2020). Polymer scaffolds as drug delivery systems. European Polymer Journal, 129(September 2019),

11. Chan, C. M., Vandi, L. J., Pratt, S., Halley, P., Richardson, D., Werker, A., Laycock, B. (2018). Composites of Wood and Biodegradable Thermoplastics: A Review. Polymer Reviews, 58(3), 444-494.

12. Chuayjuljit, S., Wongwaiwattanakul, C., Chaiwutthinan, P., Prasassarakich, P. (2017). Biodegradable poly(lactic acid)/poly(butylene succinate)/wood flour composites: Physical and morphological properties. Polymer Composites, 38(12), 2841-2851.

13. Clemons, C. (2008). Raw materials for wood-polymer composites. Wood-Polymer Composites, 1-22.

14. Cogswell, F. N., Leach, D. C. (1986). Thermoplastic Composites. 1, 75-87.

15. Dalu, M., Temiz, A., Altuntaş, E., Demirel, G. K., Aslan, M. (2019). Characterization of tanalith E treated wood flour filled polylactic acid composites. Polymer Testing, 76(April), 376-384.

16. Dong, J., Huang, X., Muley, P., Wu, T., Barekati-Goudarzi, M., Tang, Z., Li, M., Lee, S., Boldor, D., Wu, Q. (2020). Carbonized cellulose nanofibers as dielectric heat sources for microwave annealing 3D printed PLA composite. Composites Part B: Engineering, 184(November 2019), 107640.

17. dos Santos, F. A., Iulianelli, G. C. V., Tavares, M. I. B. (2017). Effect of microcrystalline and nanocrystals cellulose fillers in materials based on PLA matrix. Polymer Testing, 61, 280-288.

18. Elsawy, M. A., Kim, K. H., Park, J. W., Deep, A. (2017). Hydrolytic degradation of polylactic acid (PLA) and its composites. Renewable and Sustainable Energy Reviews, 79(May), 1346-1352.

19. Faludi, G., Dora, G., Renner, K., Móczó, J., Pukánszky, B. (2013). Improving interfacial adhesion in pla/wood biocomposites. Composites Science and Technology, 89, 77-82.

20. Gan, I., Chow, W. S. (2018). Antimicrobial poly(lactic acid)/cellulose bionanocomposite for food packaging application: A review. Food Packaging and Shelf Life, 17(July), 150-161.

21. Gregorova, A., Hrabalova, M., Wimmer, R., Saake, B., Altaner, C. (2009). Poly(lactide acid) composites reinforced with fibers obtained from different tissue types of Picea sitchensis. Journal of Applied Polymer Science, 114(5), 2616-2623.

22. Gritsch, L., Conoscenti, G., La Carrubba, V., Nooeaid, P., Boccaccini, A. R. (2019). Polylactide-based materials science strategies to improve tissue-material interface without the use of growth factors or other biological molecules. Materials Science and Engineering C, 94(September 2018), 1083-1101.

23. Guo, R., Ren, Z., Bi, H., Song, Y., Xu, M. (2018). Effect of toughening agents on the properties of poplar 
wood flour/poly (lactic acid) composites fabricated with Fused Deposition Modeling. European Polymer Journal, 107(June), 34-45.

24. Guo, Y., Ruan, K., Shi, X., Yang, X., Gu, J. (2020). Factors affecting thermal conductivities of the polymers and polymer composites: A review. Composites Science and Technology, 193(March), 108134.

25. Haghshenas, M. (2016). Metal-Matrix Composites. Reference Module in Materials Science and Materials Engineering, October 2015, 0-28.

26. Han, H., Wang, X., Wu, D. (2012). Preparation, crystallization behaviors, and mechanical properties of biodegradable composites based on poly(L-lactic acid) and recycled carbon fiber. Composites Part A: Applied Science and Manufacturing, 43(11), 1947-1958.

27. Han, S., Jin, X., Wang, J., Costa, F., Bendickson, R., Kaczmarczyk, M. (2012). The numerical analysis and validation of compression molding process. SPE Automotive and Composites Divisions - 12th Annual Automotive Composites Conference and Exhibition 2012, ACCE 2012: Unleashing the Power of Design, 3(April), 827-839.

28. Hegyesi, N., Zhang, Y., Kohári, A., Polyák, P., Sui, X., Pukánszky, B. (2019). Enzymatic degradation of PLA/cellulose nanocrystal composites. Industrial Crops and Products, 141(October), 111799.

29. Huda, M. S., Drzal, L. T., Misra, M., Mohanty, A. K. (2006). Wood-fiber-reinforced poly(lactic acid) composites: Evaluation of the physicomechanical and morphological properties. Journal of Applied Polymer Science, 102(5), 4856-4869.

30. İşmal, Ö. E., Paul, R. (2017). Composite textiles in high-performance apparel. In High-Performance Apparel: Materials, Development, and Applications.

31. Jordá-Vilaplana, A., Fombuena, V., García-García, D., Samper, M. D., Sánchez-Nácher, L. (2014). Surface modification of polylactic acid (PLA) by air atmospheric plasma treatment. European Polymer Journal, 58, 23-33.

32. Kathavate, V. S., Pawar, D. N., Bagal, N. S., Adkine, A. S., Salunkhe, V. G. (2020). Micromechanics based models for effective evaluation of elastic properties of reinforced polymer matrix composites. Materials Today: Proceedings, 21, 1298-1302.

33. Khoo, R. Z., Ismail, H., Chow, W. S. (2016). Thermal and Morphological Properties of Poly (Lactic Acid)/Nanocellulose Nanocomposites. Procedia Chemistry, 19, 788-794.

34. Koh, J. J., Zhang, X., He, C. (2018). Fully biodegradable Poly(lactic acid)/Starch blends: A review of toughening strategies. International Journal of Biological Macromolecules, 109, 99-113.

35. Koodalingam, B., Senthilkumar, P., Rajesh Babu, S. (2020). Study of mechanical properties of the polymer matrix composite materials using pistachio shells. Materials Today: Proceedings, xxxx.

36. Kowalczyk, M., Piorkowska, E., Kulpinski, P., Pracella, M. (2011). Mechanical and thermal properties of PLA composites with cellulose nanofibers and standard size fibers. Composites Part A: Applied Science and Manufacturing, 42(10), 1509-1514.

37. Kushwaha, S., Bagha, A. K. (2020). Application of composite materials for vibroacoustic - A review. Materials Today: Proceedings, xxxx.

38. Le Duigou, A., Castro, M., Bevan, R., Martin, N. (2016). 3D printing of wood fibre biocomposites: From mechanical to actuation functionality. Materials and Design, 96, 106-114.

39. Lee, S. Y., Kang, I. A., Doh, G. H., Yoon, H. G., Park, B. D., Wu, Q. (2008). Thermal and mechanical properties of wood flour/talc-filled polylactic acid composites: Effect of filler content and coupling treatment. Journal of Thermoplastic Composite Materials, 21(3), 209-223.

40. Li, Y. (2011). Wood-Polymer Composites. Advances in Composite Materials - Analysis of Natural and Man-Made Materials, September 2011.

41. Liu, D. Y., Yuan, X. W., Bhattacharyya, D., Easteal, A. J. (2010). Characterisation of solution cast cellulose nanofibre - Reinforced poly(lactic acid). Express Polymer Letters, 4(1), 26-31.

42. Loureiro, N. C., Esteves, J. L., Viana, J. C., Ghosh, S. (2014). Development of polyhydroxyalkanoates/poly(lactic acid) composites reinforced with cellulosic fibers. Composites Part B: Engineering, 60, 603-611.

43. Madhavan Nampoothiri, K., Nair, N. R., John, R. P. (2010). An overview of the recent developments in polylactide (PLA) research. Bioresource Technology, 101(22), 8493-8501.

44. Maged, A., Bhuiyan, N., Kaytbay, S., Haridy, S. (2019). Continuous improvement of injection moulding using Six Sigma: case study. International Journal of Industrial and Systems Engineering, 32(2), 243.

45. Mathew, A. P., Oksman, K., Sain, M. (2006). The effect of morphology and chemical characteristics of cellulose reinforcements on the crystallinity of polylactic acid. Journal of Applied Polymer Science, 101(1), 300-310.

46. Muley, S., Nandgude, T., Poddar, S. (2016). Extrusion-spheronization a promising pelletization technique: In-depth review. Asian Journal of Pharmaceutical Sciences, 11(6), 684-699.

47. Nagaraja, K. C., Rajanna, S., Prakash, G. S., Rajeshkumar, G. (2020). Mechanical properties of polymer matrix composites: Effect of hybridization. Materials Today: Proceedings, xxxx, 2019-2021. 
48. Ozyhar, T., Baradel, F., Zoppe, J. (2020a). Effect of functional mineral additive on processability and material properties of wood-fiber reinforced poly(lactic acid) (PLA) composites. Composites Part A: Applied Science and Manufacturing, 132, 105827.

49. Ozyhar, T., Baradel, F., Zoppe, J. (2020b). Effect of functional mineral additive on processability and material properties of wood-fiber reinforced poly(lactic acid) (PLA) composites. Composites Part A: Applied Science and Manufacturing, 132(July), 3743-3753.

50. Perić, M., Putz, R., Paulik, C. (2019). Influence of nanofibrillated cellulose on the mechanical and thermal properties of poly(lactic acid). European Polymer Journal, 114(March), 426-433.

51. Qian, S., Sheng, K. (2017). PLA toughened by bamboo cellulose nanowhiskers: Role of silane compatibilization on the PLA bionanocomposite properties. Composites Science and Technology, 148, 5969.

52. Raj, S. S., Kannan, T. K., Kathiresan, M., Balachandar, K., Krishnakumar, S. (2020). Why not stir casting for polymer composites? Investigations on poly lactic acid based wood plastic composite. Materials Today: Proceedings, $x x x x$.

53. Ramesh, M. (2016). Kenaf (Hibiscus cannabinus L.) fibre based bio-materials: A review on processing and properties. Progress in Materials Science, 78-79, 1-92.

54. Ramu, P., Jaya Kumar, C. V., Palanikumar, K. (2019). Mechanical characteristics and terminological behavior study on natural fiber nano reinforced polymer composite - A review. Materials Today: Proceedings, 16, 1287-1296.

55. Riley, A. (2012). Basics of polymer chemistry for packaging materials. In Packaging Technology. Woodhead Publishing Limited.

56. Rowell, R. M. (1984). Penetration and Reactivity of Cell Wall Components. The Chemistry Of Solid Wood, pp.175-210.

57. Sabari Narayanan, G., Senthil Kumar, K. (2020). Study of mechanical properties of the polymer matrix composite material (solid wool). Materials Today: Proceedings, xxxx.

58. Saeed, U., Nawaz, M. A., Al-Turaif, H. A. (2018). Wood flour reinforced biodegradable PBS/PLA composites. Journal of Composite Materials, 52(19), 2641-2650.

59. Sarangi, S., Sinha, A. K. (2016). Mechanical properties of hybrid fiber reinforced concrete. Indian Journal of Science and Technology, 9(30), 1-21.

60. Saxena, M., Pappu, A., Sharma, A., Haque, R., Wankhede, S. (2011). Composite Materials from Natural Resources: Recent Trends and Future Potentials. Advances in Composite Materials - Analysis of Natural and Man-Made Materials, September.

61. Shah, B. L., Selke, S. E., Walters, M. B., Heiden, P. A. (2008). Effects of wood flour and chitosan on mechanical, chemical, and thermal properties of polylactide. Polymer Composites, 29(6), 655-663.

62. Silva, T. F. da, Menezes, F., Montagna, L. S., Lemes, A. P., Passador, F. R. (2019). Effect of lignin as accelerator of the biodegradation process of poly(lactic acid)/lignin composites. Materials Science and Engineering B: Solid-State Materials for Advanced Technology, 251(May), 114441.

63. Silvester, F. D. (1967). Structure of Wood. Timber, pp. 8-13.

64. Spiridon, I., Darie, R. N., Kangas, H. (2016). Influence of fiber modifications on PLA/fiber composites. Behavior to accelerated weathering. Composites Part B: Engineering, 92, 19-27.

65. Tao, Y., Wang, H., Li, Z., Li, P., Shi, S. Q. (2017). Development and application ofwood flour-filled polylactic acid composite filament for 3d printing. Materials, 10(4), 1-6.

66. Teuber, L., Osburg, V. S., Toporowski, W., Militz, H., Krause, A. (2016). Wood polymer composites and their contribution to cascading utilisation. Journal of Cleaner Production, 110, 9-15.

67. Vasiliev, V. V., Morozov, E. V. (2018). Introduction. Advanced Mechanics of Composite Materials and Structures, xvii-Xxv.

68. Wang, R.-M., Zheng, S.-R., Zheng, Y.-P. (2011). Introduction to polymer matrix composites. Polymer Matrix Composites and Technology, 1-548.

69. Wang, Z., Xu, J., Lu, Y., Hu, L., Fan, Y., Ma, J., Zhou, X. (2017). Preparation of 3D printable micro/nanocellulose-polylactic acid (MNC/PLA) composite wire rods with high MNC constitution. Industrial Crops and Products, 109(October), 889-896.

70. Wei, L., Agarwal, U. P., Matuana, L., Sabo, R. C., Stark, N. M. (2018). Performance of high lignin content cellulose nanocrystals in poly(lactic acid). Polymer, 135, 305-313.

71. Wei, L., Stark, N. M., Sabo, R. C., Matuana, L. (2016). Modification of Cellulose Nanocrystals (CNCs) for use in Poly(lactic acid) (PLA)-CNC Composite Packaging Products. June.

72. Yang, T. C. (2018). Effect of extrusion temperature on the physico-mechanical properties of unidirectional wood fiber-reinforced polylactic acid composite (WFRPC) components using fused depositionmodeling. Polymers, 10(9).

73. Zhang, C. (2014). Understanding the wear and tribological properties of ceramic matrix composites. Advances in Ceramic Matrix Composites: Second Edition, 401-428. 
74. Zhang, Y., Cui, L., Xu, H., Feng, X., Wang, B., Pukánszky, B., Mao, Z., Sui, X. (2019). Poly(lactic acid)/cellulose nanocrystal composites via the Pickering emulsion approach: Rheological, thermal and mechanical properties. International Journal of Biological Macromolecules, 137, 197-204.

75. Zhu, J., Xue, L., Wei, W., Mu, C., Jiang, M., Zhou, Z. (2015). Lignin PLA bio-composites. BioResources, 10(3), 4315-4325. 